\title{
Effect of lead rubber bearing on seismic response of regular and irregular frames in elevation
}

\author{
Kurşun çekirdekli kauçuk izolatörün yükseklik boyunca düzenli ve \\ düzensiz çerçevelerin sismik tepkisine etkisi
}

\author{
Ahmet Hilmi DERINGÖL1 * iD , Esra METE GÜNEYISİ ID \\ 1,2Department of Civil Engineering, Engineering Faculty, Gaziantep University, Gaziantep, Turkey. \\ aderingol@gmail.com, eguneyisi@gantep.edu.tr
}

\begin{abstract}
Base isolations are acknowledged as an effective seismic protective system for structural systems of buildings. This study investigates the effectiveness of lead rubber bearing (LRB) on the nonlinear response of the steel moment resisting frames subjected to real ground motions. To this aim, 12-storey regular and irregular steel frames in elevation upgraded with LRB were studied by evaluating the local and global deformations. LRB was modeled by considering three key parameters of isolation period, effective damping ratio, and stiffness ratio. Twodimensional model of the base isolated frames were created and a series of time-history analyses were carried out by different earthquake ground motions. The seismic behaviour of the bare and isolated frames was measured by the variation of isolator displacement, acceleration, interstorey drift ratio, relative displacement, roof drift ratio, normalized base shear, base moment, and hysteretic curve. The supremacy of the base-isolated frames over the bare frames was discussed accordingly. It was found that the seismic response of the regular and irregular frames in elevation could be improved up to a certain degree by implementing $L R B$.
\end{abstract}

Keywords: Base isolation, Frame, Irregular in elevation, Lead rubber bearing, Seismic performance.

\section{Introduction}

Base isolation is a novel mature method used for mitigating the destructive influences of the seismic excitations in the structures. The popularity of base isolation for the retrofitting of the structures has been particularly increased after 1995 Kobe earthquake [1]. The concept of such system depends on the decoupling the building from lateral force of the ground motions by placing the bearings [2]. During the seismic excitations, these bearings eliminated the seismic forces and deformed instead of main component of the buildings. They can be categorized in two groups, namely, sliding and elastomeric bearing systems [3]. The former enables to eliminate the seismic forces by allowing frictional surface. On the other hand, the latter provides for dissipating the seismic forces thank to the rubber sheet having less rigidity. According to supplementary damping, material properties, and performances, the elastomeric isolators are developed and subdivided into three different categories such as natural rubber bearing, high damping rubber bearing, and lead rubber bearing (LRB) [3],[4]. Compared to other elastomeric bearing system, LRB is most widely preferred isolation system since it

\section{Öz}

Taban izolatörleri binaların yapısal sistemleri için etkili bir sismik koruyucu sistem olarak kabul edilmektedir. Bu çalıșmada, kurșun çekirdekli kauçuk izolatörlerin (KÇKI) deprem kayıtlarına maruz birakılmıs moment aktaran çelik yapılar üzerinde etkinliği araştırılmıștır. Bu amaçla, KÇKİ ile iyileştirilmiş 12 katlı yükseklik boyunca düzenli ve düzensiz çelik yapılar, olușan bölgesel ve genel deformasyonlar dikkate alınarak incelenmiştir. KÇKí; izolatör periyodu, efektif sönüm oranı ve rijitlik oranı gibi üç önemli parametre kullanılarak modellenmiștir. Taban izolatörlü çelik yapıların 2 boyutlu modelleri oluşturularak farkl depremler altında zaman tanıml analizleri yapılmıștır. İzole edilmis ve edilmemis çerçevelerin sismik davranışlarl; izalatör deplasmanı, ivme, katlar arası ötelenme oranı, göreli yer değiştirme, çatı katı ötelenmesi, normalize edilmiş taban kesme kuvveti, taban momenti ve histeretik eğrileriyle değerlendirilmiştir. İzole edilmiş çerçevelerin izole edilmemiş olanlara kıyasla sağladığı avantajlar tartıșılmıștır. KÇKİnin uygulanmasıyla yükseklik boyunca düzenli ve düzensiz çerçevelerin sismik tepkilerinin belirli bir düzeye kadar iyileștirilebileceği gözlemlenmiștir.

Anahtar kelimeler: Cerçeve, Kurșun çekirdekli kauçuk izalatör, Sismik performans, Taban izolasyonu, Yükseklik boyunca düzensizlik.

has simple preliminary design procedure, minimum initial and maintenance cost [5],[6]. There is fixing steel surfaces placed at the top and bottom of the bearing, many sequenced slim layers, and lead core in the middle part of the rubber as depicted in Figure 1 [7].

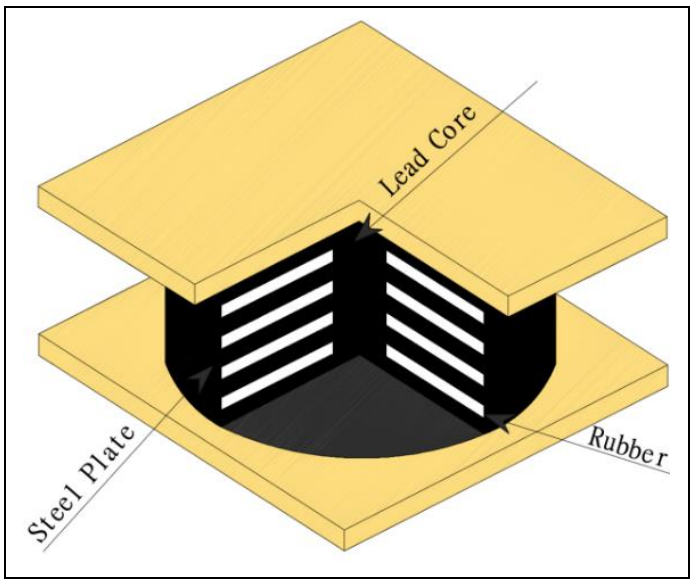

Figure 1. Typical configuration of LRB isolator [7].

${ }^{*}$ Corresponding author/Yazışılan Yazar 
The horizontal movement capacity of the bearing depends on the mechanical behaviour of the elastomeric material while the load carrying capacity of the bearing relies on the vertical stiffness of the lead core dissipated the induced seismic energy. When the base-isolated structure exposed to the ground motions, the shear deformation occurs on the rubber layers, the seismic energy is dissipated by yielding of the lead core [8]. Two different models can be used to represent the behaviour of LRB: (a) a linear viscoelastic response model for describing the rubber layer and (b) a linear elastic perfectly plastic model for the lead plug [9]. These models are adopted considering the bilinear hysteretic behaviour, as indicated in Figure 2 [10].

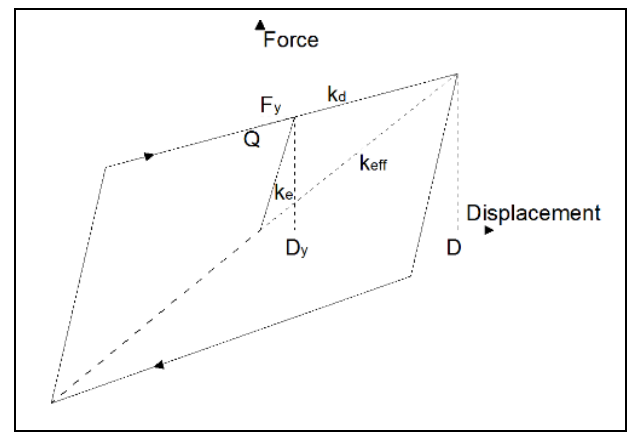

Figure 2. Hysteretic behaviour of LRB isolator [10].

Many researchers have analytically and experimentally studied the response of the base isolated systems [2],[5],[7],[11]-[21]. For example, in the analytical study of Jangid [11], the performance of the base isolated structures (buildings and bridges) was assessed through time history analyses by using six different near-field records. It was reported that the minimum response of the acceleration and displacement obtained when the ratio of the yield strength over the structure weight selected between $10-15 \%$. Bhandari et al. [12] investigated the effect of four lateral load patterns in the pushover analysis to appraisal the seismic demands of 5 and 10 -storey base isolated frames under far-field and near-field earthquakes. The results showed that the errors in predicting the number of plastic hinges were more for the far-field earthquakes in comparison to the near-field earthquakes for all load patterns. Providakis [7] carried out a series of nonlinear static analysis for evaluating the seismic response of composite structures equipped with LRB and investigated the effect of the bearing dimension regarding three different models. In addition, Liang et al. [13] studied the structural performance of the base isolated frames under wind excitation. It was noted that high-rise buildings could be easily exposed to wind events such as typhoons, storms. Kulkarni and Jangid [14] also worked the effect of the structure rigidity on different base-isolated frames having elastomeric and sliding isolators were assessed by conducting rigid and flexible model. In addition to this, Fragiacomo et al. [15] introduced a simple design procedure that utilized the optimum design parameter of the isolation systems such as mass, strength, elastic and plastic stiffness. The linear analyses were performed under different ground motions and the results of those showed that the maximum relative displacement and input energy dramatically reduced. Matsagar and Jangid [16] also examined the seismic behaviour of the multi-storey structure with different hysteretic model of the base isolated system. The response of the system was notably affected by the variation of the system parameters of isolator yield displacement, isolation period, and number of storey. Alhan and Şahin [17] examined the effect of the flexibility, damping ratio, and type of the isolation models on the base isolated systems. Three different buildings were subjected to near-fault records of five different earthquakes. As expected, the flexible isolated structures caused greater storey acceleration than the rigid ones. Although the smaller yield strength brought about drop on the storey acceleration, the variation of the isolation period had not consistent effect. The acceleration response of the isolated structures was escalated by increasing of the yield force and damping ratio while it did not vary with seismic frequency. In another study by Özdemir and Akyüz [18], 7-storey reinforced concrete base isolated buildings subjected to bidirectional excitations of the near-field ground motions was studied in order to show the variation of the floor accelerations in the base isolated structures as a function of the design properties of the isolation system. Das and Mishra [19] also proposed an extensive study on the development of the LRB by using advanced material, remarkable hysteretic behaviour and lesser yield displacement as distinctive feature of the base isolation systems, thus shape memory alloy rubber bearing was presented as modified version of LRB. The supremacy of this bearing over the traditional LRB was performed by the nonlinear random ground motions. The results reported that the modified LRB caused less acceleration and more efficiency when period of the isolator increased. In another study by Bhagat and Wijeyewickrema [20], the seismic performance of 4,8 , and 12 storey base-isolated reinforced concrete buildings subjected to bidirectional near-fault motions was evaluated by adopting material and geometric nonlinearities of the isolation system. It was observed that the base isolated structures had a supremacy over the fixed base structure in terms of interstorey drift, shear force, and floor acceleration even for 12-storey flexible structure.

In the current study, the effect of using LRB isolation system on the regular and irregular steel structures was investigated by means of the time history analyses. For this, one regular steel moment resisting frame (RF) and two irregular frames with different setbacks (IRF-1 and IRF-2) were considered. A certain value of the isolation parameters (e.g., $T=3 \mathrm{~s}, \beta=0.15$, and $\mathrm{k}_{\mathrm{d}} / \mathrm{k}_{\mathrm{e}}=0.1$ ) were introduced in order to create distinctive LRB model that is capable of performing better seismic performance. The fixed based and base isolated frames were analyzed using different natural accelerograms. The contribution of LRB inclusion into the regular and irregular steel frames was discussed comparatively based on the structural response.

\section{Analytical modeling of frames}

With the intention of examining the compatibility and effectiveness of LRB on regular and irregular structures, 12-storey steel moment resisting frame, originally designed by Karavasilis et al. [22], was selected and denoted as regular frame (RF) in elevation (without any setbacks) as seen in Figure 3a. The storey height and bay width of the frame are 3 and $5 \mathrm{~m}$, respectively. For the member section of the frame, an alteration in column and beam sections at every three storeys was adopted. For example, the first three storeys have columns and beams with sections of HEB340 and IPE450, respectively while the next three ones contain columns and beams with sections of HEB 300 and IPE 400, respectively.

The first and second periods of vibration of 12 -storey RF was reported as 2.11 and $0.77 \mathrm{~s}$, respectively. The beams possess a gravity load of $27.5 \mathrm{kN} / \mathrm{m}$. 


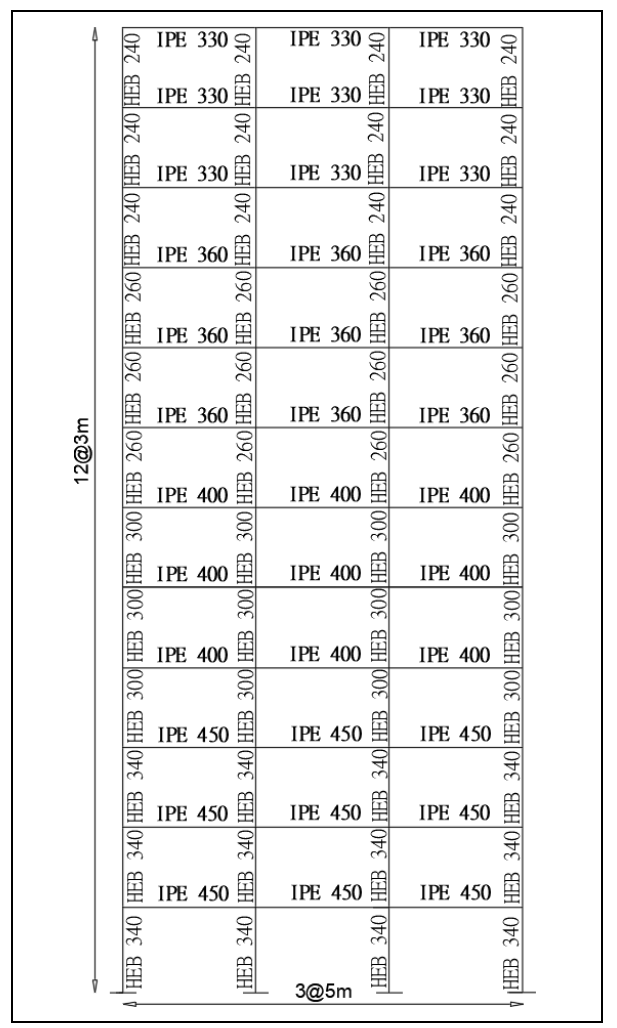

(a)

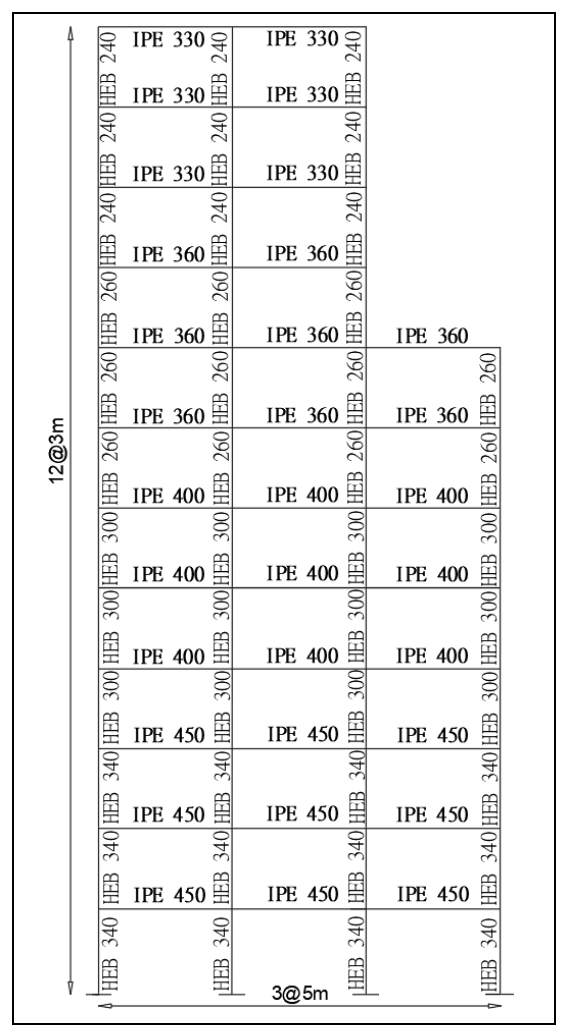

(b)

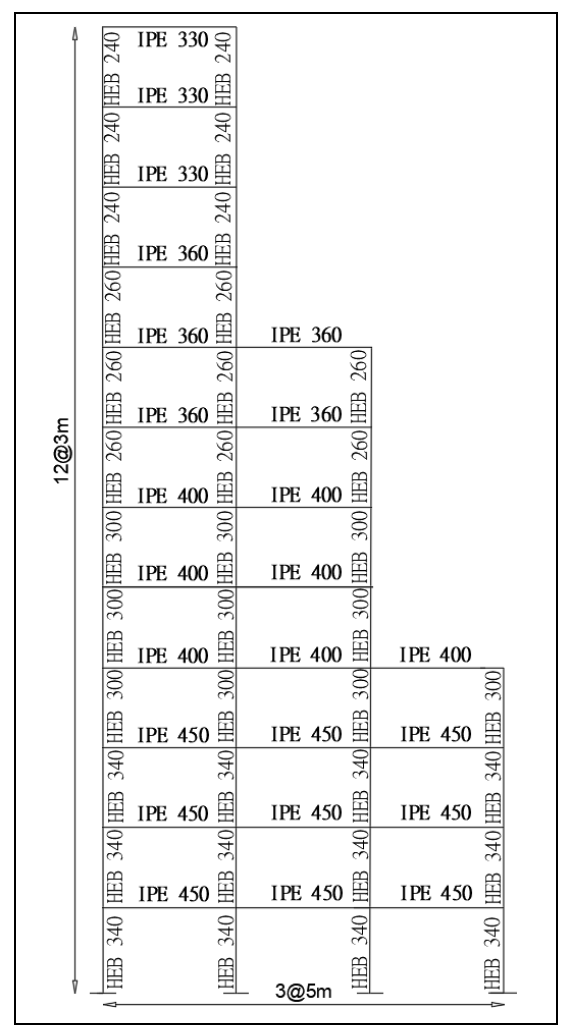

(c)

Figure 3. 12-storey frames: (a): RF [22]. (b): IRF1, and (c): IRF2.

The yield stress of the material is $235 \mathrm{MPa}$ while the post yield stiffness ratio is 0.03 . In the case of the irregular frame, as also shown in Figure 3b-3c, two irregular frames in elevation were used. They have the same configuration in lower four storeys and setbacks in the upper ones. At IRF1 case, the setback is in the upper four storeys while that is in the upper eight storeys at IRF2. Many standards like ASCE [23], Eurocode [24], TSCB [25] includes regulations for the design of structures with base isolation systems. Among the base isolation systems, LRB is the one that generally consists of steel plates located at the top and bottom of the bearing, many alternating layers of elastomers and steel shims and in the middle lead core as shown in Figure 1 [7]. The elastomeric material is designed for the lateral flexibility with the isolation component; the lead core utilizes the energy dissipation, while the inner steel shims carry the vertical load capacity of the bearing. The steel shims, together with the top and bottom steel fixing plates, also confine the central lead core. When the structure is hit by the earthquake, the lead core starts to yield and the rubber layer also deforms laterally by shear deformation, both providing the movement of the structure horizontally and growing the energy dissipation [8]. As previously mentioned, a linear viscoelastic element represented by the rubber and a linear elasticperfectly plastic element stimulated by the lead plug can be considered to model LRB [9] and its response relationship is bilinear, as given in Figure 2 [10]. Design parameter of LRB was computed by an iterative solution in accordance with Naeim and Kelly [26] to create distinctive LRB model. After making an assumption for the maximum isolator displacement, $D_{y}$ is neglected and $Q$ is estimated, it is then possible to estimate $\mathrm{k}_{\mathrm{d}}$, assuming, for instance, $T=3 \mathrm{~s}, \beta=0.15$ and $\mathrm{k}_{\mathrm{e}}=10 \mathrm{k}_{\mathrm{d}}$, and then the iteration started and until the calculated and obtained value of $D_{y}$ were almost the same. In the iterative procedure described in Naeim and Kelly [26], the following equations were used. The assumed value of the isolation period $\mathrm{T}$ was then used to calculate the effective stiffness, keff;

$$
T=2 \pi \sqrt{\frac{W}{k_{e f f} x g}}
$$

post-yield stiffness of the isolator, $\mathrm{k}_{\mathrm{d}}$;

$$
k_{\text {eff }}=k_{d}+\frac{Q}{D}
$$

damping reduction factor, $\mathrm{B}$;

$$
\frac{1}{B}=0.25\left(1-\ln \beta_{e f f}\right)
$$

displacement of isolation, $\mathrm{D}$;

$$
D=\frac{g S_{a} T_{e f f}}{B 4 \pi^{2}}
$$

yield displacament, $\mathrm{D}_{\mathrm{y}}$;

$$
\beta_{\text {eff }}=\frac{4 Q x\left(D-D_{y}\right)}{2 \pi x k_{\text {eff }} x D^{2}}
$$

and yield strength, $\mathrm{F}_{\mathrm{y}}$

$$
F_{y}=Q+k_{d} \times D_{y}
$$


where $\mathrm{Q}$ is characteristic strength, $\mathrm{T}$ is target period, $\mathrm{W}$ is total weight on the isolator, $\mathrm{g}$ is gravitational force, $\mathrm{B}$ is damping reduction factor, $D$ is maximum displacement of isolators, $D_{y}$ is yield displacement, and $S_{a}$ is spectral acceleration. Ryan and Chopra [27] recommended fixing the yield displacement instead of fixing $\mathrm{ke}_{\mathrm{e}} / \mathrm{k}_{\mathrm{d}}$ as $10 \mathrm{~mm}$ while Naeim and Kelly [26] proposed a constant value for the ratio of post yield stiffness $\left(\mathrm{k}_{\mathrm{d}}\right)$ to initial stiffness $\left(\mathrm{k}_{\mathrm{e}}\right)$ for LRBs. In this study, $\mathrm{k}_{\mathrm{d}} / \mathrm{k}_{\mathrm{e}}$ is assumed as 0.1 and LRB was designed by a generic bilinear hysteretic force deformation relation as shown in Figure 2 [10]. In addition, the isolation period of $3.0 \mathrm{~s}$, the corresponding effective damping ratio $\beta=15.0 \%$ and stiffness ratio, $\mathrm{k}_{\mathrm{d}} / \mathrm{k}_{\mathrm{e}}=0.1$ were chosen in order to cover appropriate range of isolation system features. Since the yield strength ratio is depended substantially on the selection of the isolation parameters and properties of structures, in the current study, this value was obtained as about $3.7 \%$. The properties of the isolation systems were calculated using Eqs. (1)-(6) and illustrated in Table 1 for 12 -storey frames. It was noted that each isolation model was labeled based on their frame types as to utilize in figures and throughout the rest of the text. For example, RF-LRB denotes an isolation model, regular frame equipped with LRB.

The mechanical characteristics of the base isolated models were calculated in accordance with the upcoming forces to four different bearings located to base of the investigated models that include rubber isolator as a nonlinear link element employed by Park et al. [28]. A sample elevation view of 12storey IRF-2 with LRB is represented in Figure 4.

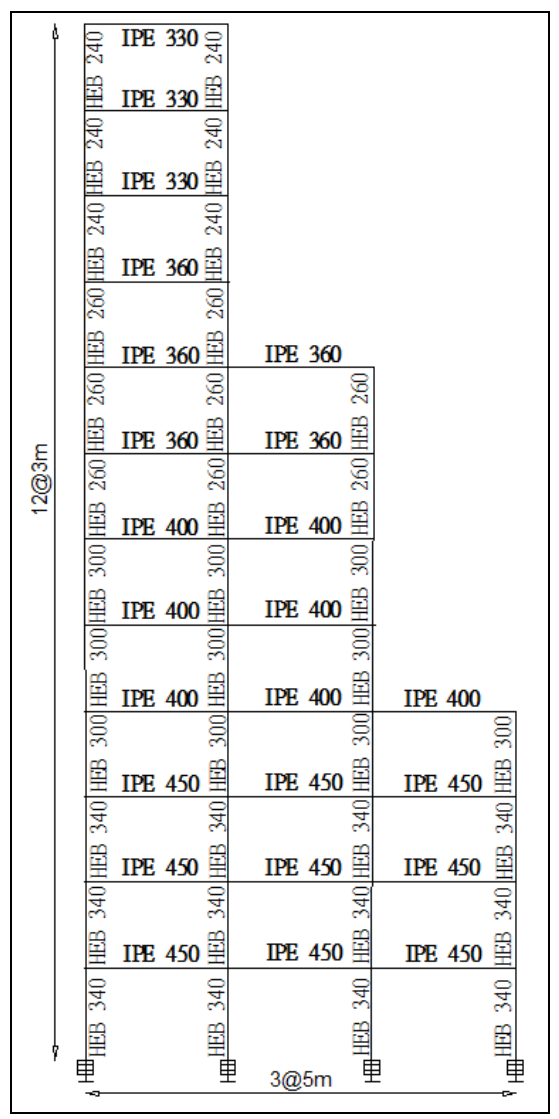

Figure 4. 12-storey IRF2 with LRB.

Thus, isolation models for 12-storey RF, IRF-1, and IRF-2 with LRB were considered as base isolation system in this study. The analytical models of all frame cases were performed by the computer tool of SAP 2000 [29]. At the end of the nonlinear time-history analyses, inertial forces were computed by means of the seismic excitations and response of the case study frames with and without LRB were determined considering the variation of forces and displacements with time. Seismic records given in Table 2 were obtained from the strong motion database of Pacific Earthquake Engineering Research Center [30] according to ASCE 7-10 [31] in which the average value of the $5 \%$ damped response spectra for the suite of motions is not less than the design response spectrum for the site for periods ranging from $0.2 \mathrm{~T}$ to $1.5 \mathrm{~T}$ where $\mathrm{T}$ is the natural period of the structure. Furthermore, the acceleration spectrum of the earthquake ground motion records utilized are plotted in Figure 5.

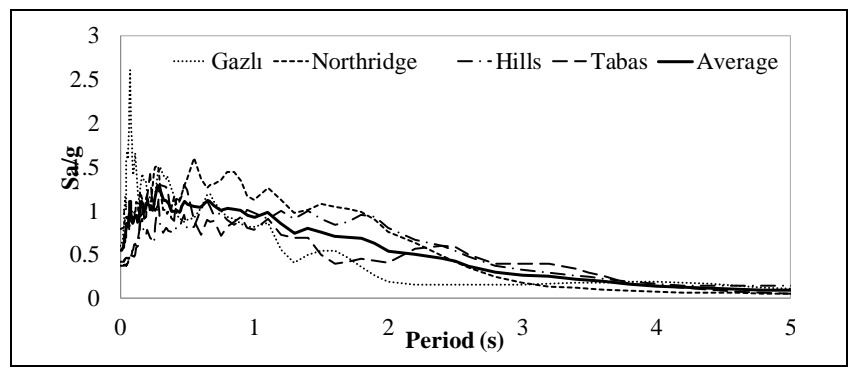

Figure 5. Acceleration spectrum of the ground motion records.

\section{Discussion of results}

The present study were investigated the dynamic characteristic and seismic response of 12-storey regular and irregular steel frames equipped with and without LRB. In this regard, the behaviour of the bare and isolated frames were evaluated considering the following parameters; the maximum isolator displacement, roof displacement/drift ratio, maximum and storey acceleration, relative displacement, maximum interstorey drift ratio, normalized base shear, base moment, dissipated energy, and hysteretic curve computed from inelastic time-history analyses.

The maximum isolator displacement of 12-storey base isolated frames were computed in accordance with the corresponding earthquakes through the nonlinear analyses and plotted as shown in Figure 6. The setbacks on the isolated frames affected the isolator displacement, and it was observed that the isolator displacement demand of IRF2-LRB was greater than IRF1-LRB and RF-LRB. For example, the maximum isolator displacement of 23,1, 22.1, 48.3, and $69.2 \mathrm{~cm}$ was obtained when IRF2-LRB subjected to Gazl, Northridge, Hills, and Tabas earthquakes, respectively. Moreover, the average values of the isolator displacement were slightly greater than the assumed initial isolator displacement.

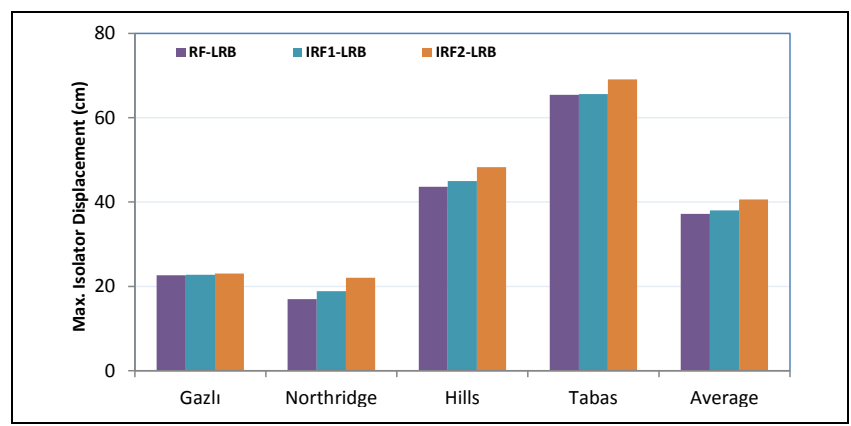

Figure 6. Maximum isolator displacement of 12-storey isolated frames under earthquakes. 
Table 1. Properties of LRB for columns (left to right) in 12-storey base-isolated frames.

\begin{tabular}{|c|c|c|c|c|c|c|c|c|c|c|c|}
\hline Model & Load (kN) & $\mathrm{D}_{\mathrm{y}}(\mathrm{mm})$ & $\mathrm{F}_{\mathrm{y}}(\mathrm{kN})$ & $\mathrm{k}_{\mathrm{e}}(\mathrm{kN} / \mathrm{m})$ & $\mathrm{k}_{\mathrm{d}}(\mathrm{kN} / \mathrm{m})$ & \multicolumn{2}{|c|}{$\mathrm{D}(\mathrm{m})$} & $\mathrm{k}_{\mathrm{eff}}(\mathrm{kN} / \mathrm{m})$ & & \multicolumn{2}{|c|}{ Location } \\
\hline & 799.3 & 10.9 & 29.3 & 2698.1 & 269.8 & \multicolumn{2}{|c|}{0.302} & 357.1 & & \multicolumn{2}{|c|}{$1^{\text {st-column }}$} \\
\hline \multirow[t]{4}{*}{ RF-LRB } & 1429.4 & 10.9 & 52.5 & 4825.4 & 482.5 & \multicolumn{2}{|c|}{0.302} & 638.5 & & \multicolumn{2}{|c|}{$2^{\text {nd }}$-column } \\
\hline & 799.3 & 10.9 & 29.3 & 2698.1 & 269.8 & \multicolumn{2}{|c|}{0.302} & 357.1 & & \multicolumn{2}{|c|}{$3^{\text {rd-column }}$} \\
\hline & 1429.4 & 10.9 & 52.5 & 4825.5 & 482.5 & \multicolumn{2}{|c|}{0.302} & 638.5 & & \multicolumn{2}{|c|}{$4^{\text {th }}$-column } \\
\hline & 800.9 & 10.9 & 29.4 & 2703.9 & 270.3 & & & 357.8 & & $1^{\text {st }}$ - & \\
\hline \multirow[t]{4}{*}{ IRF1-LRB } & 1406.7 & 10.9 & 51.6 & 4748.7 & 474.8 & \multicolumn{2}{|c|}{0.302} & 628.4 & & \multicolumn{2}{|c|}{$2^{\text {nd }}$-column } \\
\hline & 1233.4 & 10.9 & 45.3 & 4163.8 & 416.3 & \multicolumn{2}{|c|}{0.302} & 550.9 & & \multicolumn{2}{|c|}{$3^{\text {rd }}$-column } \\
\hline & 531.1 & 10.9 & 19.5 & 1792.6 & 179.2 & \multicolumn{2}{|c|}{0.302} & 237.2 & & \multicolumn{2}{|c|}{$4^{\text {th }}$-column } \\
\hline & 774.9 & 10.9 & 28.4 & 2615.8 & 261.5 & & & 346.1 & & $1^{\text {st }}$ - & \\
\hline \multirow[t]{3}{*}{ IRF2-LRB } & 1192.1 & 10.9 & 43.7 & 4024.1 & 402.4 & \multicolumn{2}{|c|}{0.302} & 532.5 & & \multicolumn{2}{|c|}{$2^{\text {nd }}$-column } \\
\hline & 774.9 & 10.9 & 28.4 & 2615.8 & 261.5 & \multicolumn{2}{|c|}{0.302} & 346.1 & & \multicolumn{2}{|c|}{$3^{\text {rd }}$-column } \\
\hline & 252.1 & 10.9 & 9.3 & 851.1 & 85.1 & \multicolumn{2}{|c|}{0.302} & 112.6 & & \multicolumn{2}{|c|}{$4^{\text {th }}-$ column } \\
\hline Earthquake & Year & & ion & Mechanism & $\mathrm{M}_{\mathrm{w}}$ & $\begin{array}{c}\mathrm{R}_{\mathrm{jb}} \\
(\mathrm{km})\end{array}$ & $\begin{array}{c}\text { Rrup } \\
(\mathrm{km})\end{array}$ & $\begin{array}{c}V_{s 30} \\
(m / s)\end{array}$ & $\begin{array}{l}\text { PGA } \\
(\mathrm{g})\end{array}$ & $\begin{array}{c}\text { PGV } \\
(\mathrm{cm} / \mathrm{s})\end{array}$ & $\begin{array}{l}\text { PGD } \\
(\mathrm{cm})\end{array}$ \\
\hline Gazlı & 1976 & & akyr & - & 6.8 & 3.9 & 5.5 & 659.6 & 0.59 & 64.94 & 24.18 \\
\hline Northridge & 1994 & Sylma & onverter & Reverse & 6.69 & 0 & 5.3 & 251.2 & 0.79 & 93.29 & 53.29 \\
\hline Superstition Hills & 1987 & Parach & Test Site & Strike-Slip & 6.54 & 0.9 & 0.9 & 348.7 & 0.41 & 106.74 & 50.54 \\
\hline Tabas & 1978 & & oas & Reverse & 7.35 & 1.8 & 2 & 766.8 & 0.80 & 118.29 & 96.80 \\
\hline
\end{tabular}

Note: $\mathrm{M}_{\mathrm{w}}$ : Magnitude; $\mathrm{R}_{\mathrm{jb}}$ : Surface projection distance; Rrup:Rupture distance; $\mathrm{V}_{\mathrm{s} 30}$ : Mean shear velocity over the top $30 \mathrm{~m}$; PGA: Peak ground acceleration; PGV: Peak ground velocity; PGD: Peak ground displacement.

The roof displacement demand of 12-storey RF, IRF-1, and IRF2 equipped with LRB predefined isolation period, effective damping ratio, and stiffness ratio under four ground motions were determined and normalized by the building height. The obtained roof drift ratio of the examined frames and average of them are given in Figure 7. It could be clearly seen that the frames supported with the LRB had generally reduced the roof drift demand. It was pointed out that the irregularity in elevation, utilization of the LRB, and characteristic of the earthquakes had notable effect on the variation of the roof drift ratio. For example, the roof drift ratio was decreased when the RF equipped with LRB under Northridge and Hills earthquakes, whereas it was conversely increased under Gazlı and Tabas earthquakes.

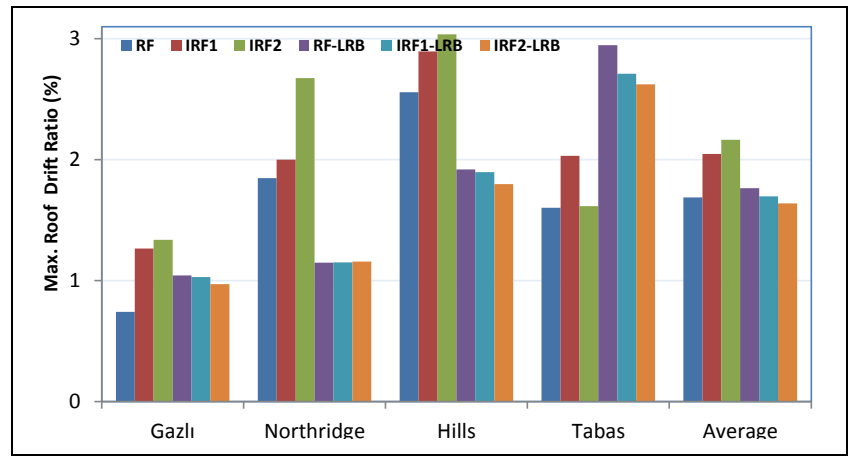

Figure 7. Maximum roof drift ratio of 12-storey frames under earthquakes.
When the irregular frames equipped with LRB and subjected to Gazl, Northridge, and Hills earthquakes, the roof drift ratio was remarkably decreased as $18.7,42.5$, and $34.4 \%$ for IRF1-LRB and $27.4,56.7$, and $40.7 \%$ for IRF2-LRB, respectively. The average roof drift ratio results also revealed that the utilization of LRB in RF caused slight increase as $4.5 \%$ whereas a reduction is observed as 17.2 and $24.4 \%$ for IRF1-LRB and IRF2-LRB, respectively. Moreover, among the examined base isolated models, the minimum roof drift ratio of $0.97 \%$ was experienced in 12-storey IRF2-LRB under Gazlı earthquake as shown in Figure 7.

The relative displacements can be evaluated as the difference between the roof and base displacement of frames; hence it can be admitted as valuable parameter in the seismic response evaluation of the frames. The maximum relative displacements of 12-storey frames with and without LRB were computed in accordance with the corresponding earthquakes through the nonlinear analyses and depicted in Figure 8.

In addition, the variation of the average relative displacement of correspondence storey level for each of the models is given in Figure 8. It could be clearly observed that the base isolated frames predefined isolation parameters $(T=3 \mathrm{~s}, B=0.15$, and $\mathrm{k}_{\mathrm{d}} / \mathrm{k}_{\mathrm{e}}=0.1$ ) had remarkably improved the relative displacement. Since the assigned stiffness of the isolator for IRFs is lower than RF (see Table 1), LRB enables to horizontal flexibility and provides also lateral movement of the structure, thus LRB effectively reduced the relative displacement. 


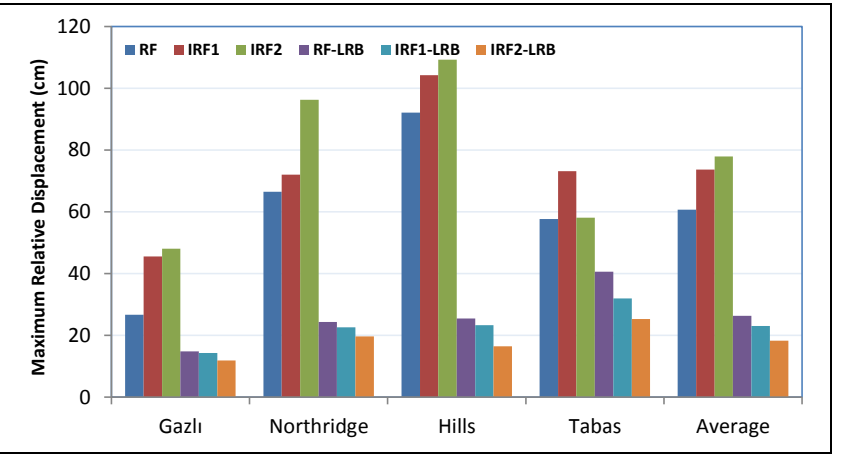

Figure 8. Maximum relative displacement of 12-storey frames under earthquakes.

Comparison of the bare frames indicated that RF remarkably caused the lowest relative displacement. Moreover, the relative displacement demand of IRF1 was lower than IRF2. As for the base isolated frames, IRF2-LRB exhibited the lowest relative displacement irrespective of the earthquakes characteristics as shown in Figure 8. Hence, the use of LRB was very effective for decreasing the relative displacement demand. In addition, it was clearly observed that the utilization of LRB in RF and IRFs tended to distribute the relative displacement demand more uniformly than the bare frames, especially for IRF2 as shown in Figure 9. The greatest reduction in the relative displacement experienced when IRF2-LRB subjected to Hills earthquake. For instance, the relative displacement demand of IRF2 was 109.29 $\mathrm{cm}$ while it was reduced up to $16.46 \mathrm{~cm}$ for IRF2-LRB as shown in Figure 8.

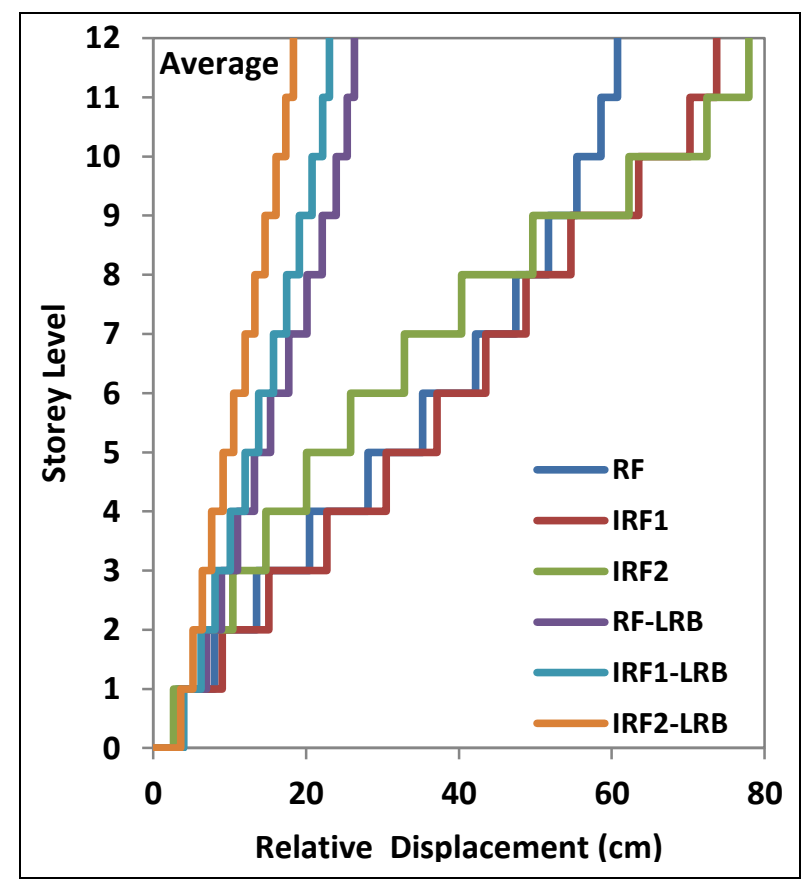

Figure 9. Variation of the average relative displacement of the frames with storey height.

The interstorey drift ratio can be acknowledged as a significant indicator for performance evaluation of the structures. It can be computed as the difference between lateral movement demands of the sequential storey normalized by the storey height. The maximum interstorey drift ratio of 12 -storey frames with and without LRB under four ground motions are given in Figure 10.

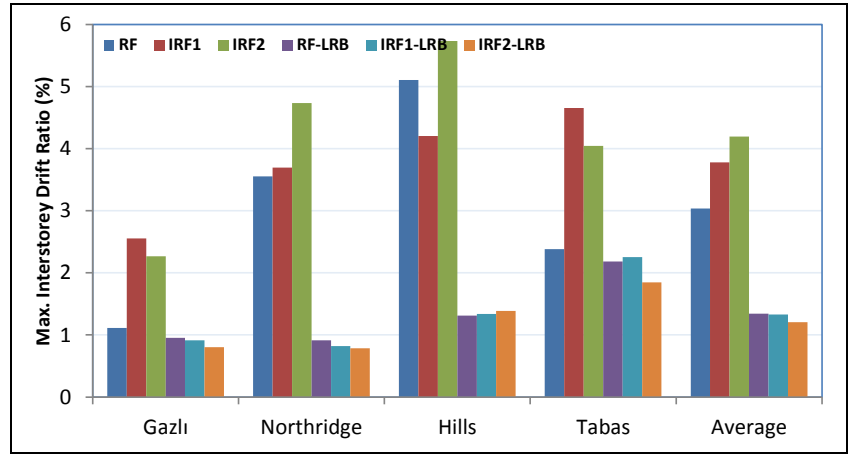

Figure 10. Maximum interstorey drift ratio of 12-storey frames under earthquakes.

The variation of the maximum interstorey drift ratio with respect to storey level of 12-storey bare and isolated frames regarding the frame types (i.e., RF, IRF1, and IRF2) subjected to Hills earthquake is illustrated in Figure 10. Firstly, compared to IRFs, RF generally performed the lowest maximum interstorey drift ratio as 1.12, 3.55, and 2.38\% under Gazll, Northridge, and Tabas earthquakes, respectively (see Figure 10). On the other hand, IRF1 exhibited the lowest maximum interstorey drift ratio as $4.20 \%$ under Hills earthquake. In addition to success with the decrease of the interstorey drift ratio for RF, the distribution of it also tended to behave more uniform over the height of RF as shown in Figure 11.

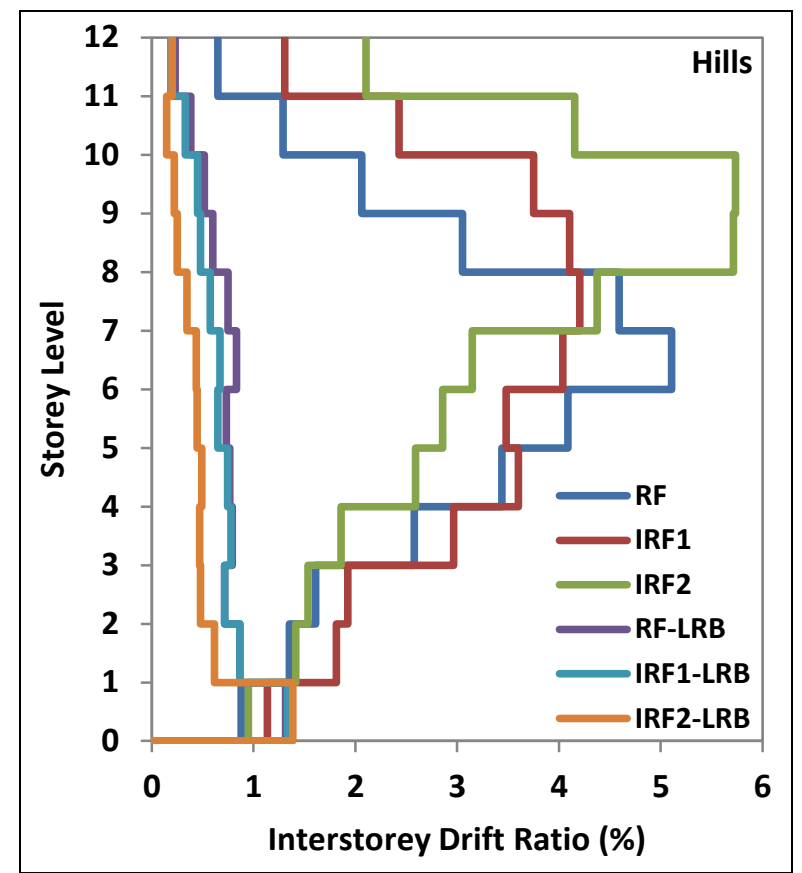

Figure 11. Variation of the interstorey drift ratio of the frames with storey height under Hills earthquake.

The frame including more irregularity in elevation resulted in more the interstorey drift ratio, for instance, IRF2 performed the maximum average interstorey drift ratio as $4.20 \%$. Secondly, when the bare frames (namely RF, IRF1, and IRF2) equipped with LRB, the maximum interstorey drift ratio of those substantially diminished, irrespective of the earthquakes. The lowest interstorey drift ratios were observed in IRFs with respect to the RF due to the use of LRB (see Figure 10). For example, the interstorey drift ratios of $0.78,0.82$, and $0.92 \%$ obtained when IRF2-LRB, IRF1-LRB, and RF-LRB hit by 
Northridge earthquake, respectively. Similarly, the most uniform distribution of the interstorey drift ratio over the height of the frames was testified for IRF2-LRB under Hills earthquake; furthermore, the utilization of LRB in IRF2 reduced the roof interstorey drift ratio from 2.10 to $0.20 \%$ (see Figure 11). Thirdly, it could be clearly seen that the earthquake characteristics slightly differentiated the interstorey drift ratio of 12-storey frames supported with and without LRB model. The variation trend of the interstorey drift ratio demand for the bare and isolated frames was steady especially for Gazll, Northridge, and Tabas earthquakes; on the contrary Hills earthquake did not have steady response. It could be testified that the inclusion of LRB in the frames having more irregularity resulted in both lower interstorey drift ratio and uniform distribution over the height of the frames as shown in Figure 11. Among bare models, RF testified to the lowest average interstorey drift ratio of $3.04 \%$ while IRF2-LRB yielded the lowest value of $1.20 \%$ for the isolated models (see Figures 10 and 11). It was clearly observed that the maximum interstorey drift ratios of all frames with LRB (namely RF-LRB, IRF1-LRB, and IRF2-LRB) were lower than $4 \%$ that is the limit state of near collapse according to SEAOC [32]. These results also verified the improved effects of the base isolated systems.

The corresponding maximum acceleration values of the frames can be observed in Figure 12. It was pointed out that the frames having more regularity remarkably performed higher absolute acceleration in all cases. Furthermore, the utilization of LRB reflected the minimum acceleration with respect to the bare frames under all earthquakes. However, the variation of the acceleration for isolated frames was not steady trend and partially changed with earthquake characteristics as shown in Figure 11. For instance, when the irregularity of the frames increased (namely varied from RF to IRF1 and IRF1 to IRF2), the maximum acceleration was entirely enhanced for Gazl, Northridge and Hills earthquakes as well as the average acceleration. On the other hand, when the bare and isolated frames subjected to Tabas earthquake, an exemption trend occurred for IRF1 that is exhibited the lowest acceleration as $1.43 \mathrm{~g}$.

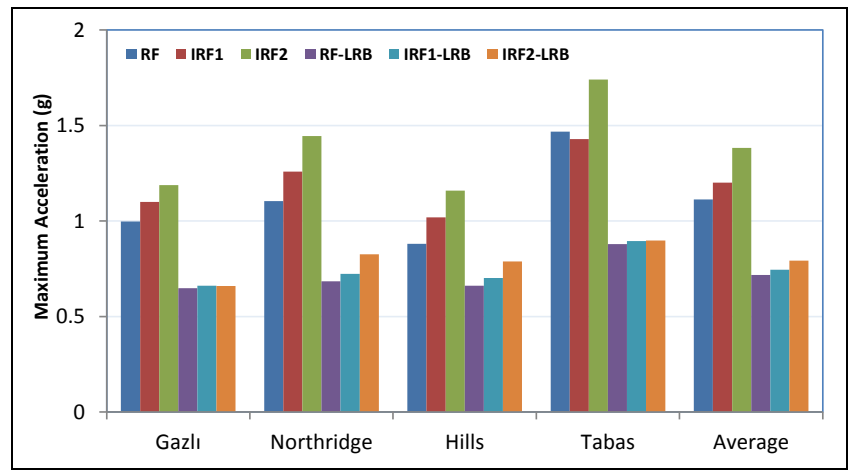

Figure 12. Maximum acceleration of 12-storey frames under earthquakes.

When IRF2 was hit by Tabas earthquake, the greatest accelerations were observed as $1.74 \mathrm{~g}$ while the lowest acceleration was obtained as $0.65 \mathrm{~g}$ for RF-LRB under Gazlı earthquake as shown in Figure 11. The variation of accelerations versus storey height under Northridge earthquakes are plotted in Figure 13. The base isolated frames exhibited similar trend on the variation of the acceleration. The accelerations over the height of the frames were observed to remain almost constant. However, for the bare frames, the variations of the accelerations over the frame heights were different. They initially increased towards mid-height, remained constant for a while and then quickly escalated towards the roof storey (see Figure 12).

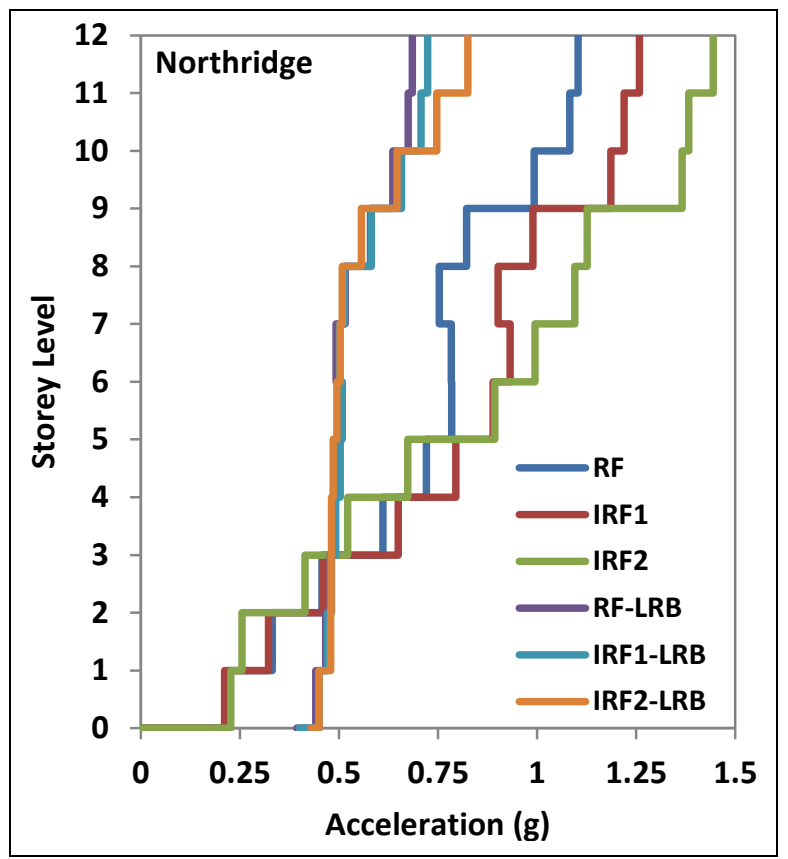

Figure 13. Variation of the acceleration of the frames with storey height under Northridge earthquake.

$\mathrm{RF}$ and RF-LRB were by far the lowest roof acceleration with respect to the IRF and IRF-LRB cases. For example, the isolation model of RF-LRB, IRF1-LRB, and IRF2-LRB were reduced the average roof acceleration by $37.6,40.1$ and $41.6 \%$ with respected to RF, IRF1, and IRF2, respectively. Among the bare and isolated 12-storey frames, the greatest average roof accelerations were observed as 1.28 and $0.75 \mathrm{~g}$ for IRF2 and IRF2-LRB while the lowest average roof absolute accelerations were obtained as $1.03,0.64 \mathrm{~g}$ for RF and RF-LRB, respectively. Figures 12 and 13 proved that both of the regular and irregular isolated frames resulted in significantly lower acceleration demand. Moreover, as shown in Figure 13, the frames with LRB exhibited the most uniform distribution of the acceleration over the height of the frames, irrespective of the amount of irregularity existed.

The base shear demand of the case study frames was computed and presented in Figure 14. The use of LRB considerably reduced the base shear demand, particularly for IRF2. To evaluate the effectiveness of the frame types and earthquake characteristics on the base shear demand, the normalized values by the building weight of RF, IRF1, and IRF2 (namely, $4890.3,4355.6$, and $3291.9 \mathrm{kN}$ ) were used. The normalized base shears were rank between 0.058-0.478 in all frames and depicted in Figure 13. It was observed that besides the variation of the frame types, the earthquake characteristics and implementation of the LRB also caused steady reduction on the base shear demand of the 12-storey frames. The inclusion of LRB under the base storey columns of 12-storey frames ensured the lowest base shear demand with regard to the bare frames, as shown in Figure 14. 


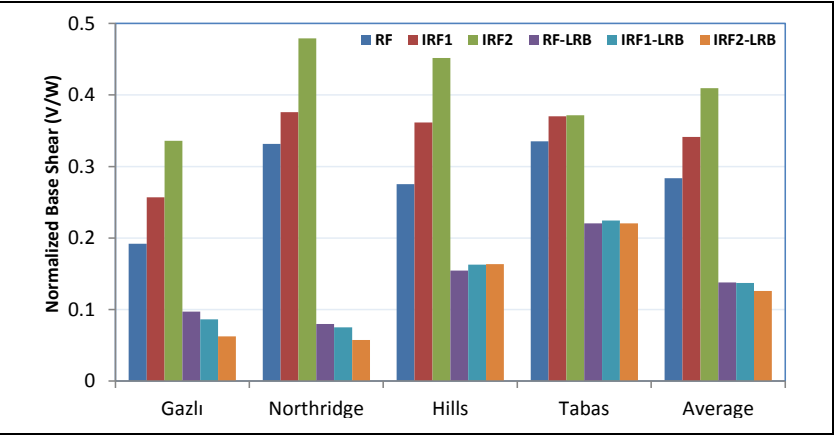

Figure 14. Maximum base shear of 12-storey frames under earthquakes.

The most remarkable base shear reduction was observed when IRF2-LRB subjected to Northridge earthquake produced the lowest normalized base shear of $0.057(280.8 \mathrm{kN})$. Similar trend on the base shear demand was also obtained under Gazlı earthquake. Additionally, the frame types quite an impression on the base shear demand and also differentiated the normalized base shear demand of the bare and isolated frames, thus similar trend was observed when the simultaneous variation of the frame types and the use of LRB. For example, when RF subjected to Northridge earthquake, the normalized base shear was obtained as $0.332(1621 \mathrm{kN})$. On the other hand, the IRFs equipped with LRB (IRF1-LRB and IRF2-LRB) which resulted in lower normalized base shear as $0.075(368.2 \mathrm{kN})$ and $0.057(280.8 \mathrm{kN})$. Similarly, 50 and $66 \%$ of the average base shear reduction was performed for RF-LRB instead of IRF1 and IRF2, respectively.

The variation of the base moment demand of the frames was plotted for four different earthquake records as shown in Figure 15. It was clearly pointed out that the utilization of LRB in the 12-storey RF and IRFs substantially mitigated the base moment, regardless of the earthquake characteristics. Similar to the base shear demand, the utilization of LRB significantly decreased the base moment of 12-storey bare and isolated frames under all earthquakes. For instance, on an average, $44.5 \%$ reduction was observed for the regular frame case with the use of LRB (RF-LRB) while up to 53.9 and $51.9 \%$ reduction was recorded for the isolated cases (IRF1-LRB and IRF2-LRB). The greatest base moments were observed under Hills earthquake as $37910 \mathrm{kNm}$ in case of IRF1 while the lowest base moments were obtained under Salvador earthquake as 10830 $\mathrm{kNm}$ in case of IRF1-LRB for 12-storey frames. Moreover, IRF2 with and without LRB presented the lowest base moment demand, as 27620 and $13293 \mathrm{kNm}$, respectively, as shown in Figure 15.

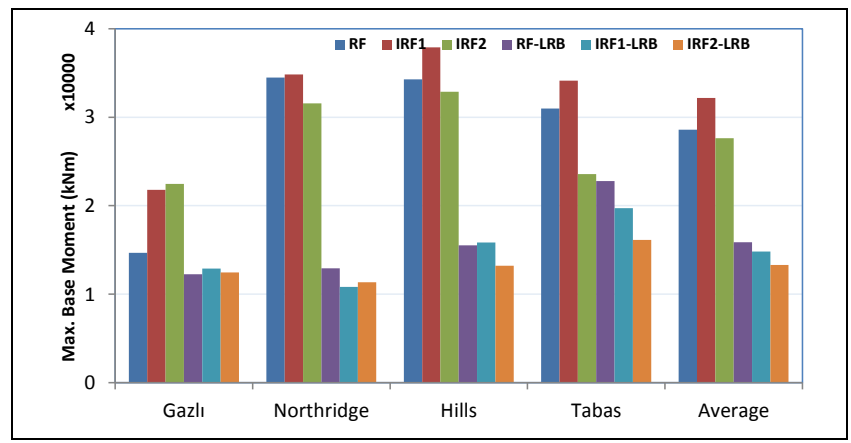

Figure 15. Maximum base moment of 12-storey frames under earthquakes.
The hysteretic curves of the LRB in the isolated frames (namely, RF-LRB, IRF1-LRB, and IRF2-LRB) under Hills earthquake is illustrated in Figure 16. These curves were similar to the bilinear force-deformation as depicted in Figure 2 [10]. The mechanical isolation parameters of the LRB utilized for RF, IRF1, and IRF2 were computed by means of the Eqns. 1-6, so three different LRB models were obtained and also the position of the hysteretic curve shifted while it abided by the original force-deformation curve. Among the isolated cases, the isolators in IRFs performed slightly larger hysteresis curves. The amount of the dissipated energy by isolators can be determined by Eqn. 7 [33].

$$
E_{\text {loop }}=4\left(D_{\max } F_{y}+F_{\text {max }} \times D_{y}\right)
$$

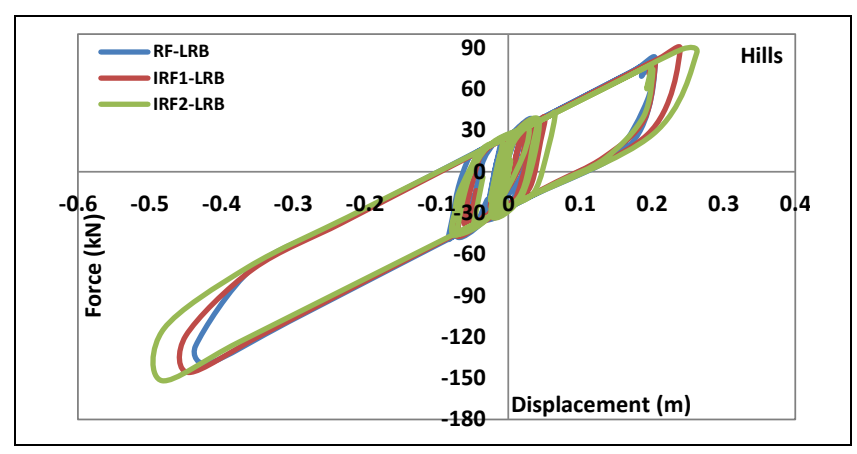

Figure 16. Hysteretic curves of LRB at 12-storey frames with LRB under Hills earthquake.

The amount of the dissipated hysteresis energy for each isolation models computed. It was observed that the isolators ensured the hysteresis energy dissipation of 52.9 and $54.8 \mathrm{~kJ}$ for IRF1-LRB and IRF2-LRB under Hills earthquake, respectively while that of RF-LRB was measured as $51.1 \mathrm{~kJ}$.

\section{Conclusions}

The contribution of the present analytical work is the investigation of the effectiveness of a specially characterized LRB base isolation system on the mitigation of seismic response of 12-storey regular and also irregular steel frames (e.g., RF, IRF-1, and IRF-2) through nonlinear dynamic time-history analyses. The positive alteration in the seismic response of both regular and especially irregular frames by these LRB systems was accentuated herein as seen from the following conclusions:

1) The seismic response of 12-storey frames was significantly influenced by the irregularity in elevation, the inclusion of LRB, and the characteristic of the earthquakes used,

2) It was depicted that the use of LRB in the bare and isolated frames with and without setbacks remarkably reduced the roof drift ratio, relative displacement, maximum interstorey drift, normalized base shear, and base moment, depending on the properties of the earthquakes,

3) The isolated models of RF, IRF1, and IRF2 were observed to behave more uniform relative displacement, interstorey drift ratio, and storey acceleration,

4) The use of appropriate isolation models remarkably yielded high dissipated hysteresis energy not only for $\mathrm{RF}$ but also for IRF cases. For instance, the LRB isolators in the models under the effect of Hills earthquake had dissipated energy up to $54.8 \mathrm{~kJ}$, 
5) The significant seismic improvement was achieved both for the regular frame and particularly for irregular frames with the use of LRB. The analysis of the results also indicated that the amount of the irregularity in frame elevation was a key factor affecting the seismic response.

6) The nonlinear time history analysis is a powerful tool, however, includes computationally demanding and time consuming process. For this, to compare the seismic response of the case studied regular and irregular frames, only four strong real ground motions were employed in the current study. However, in order to present more generalized conclusions, increase in the number of earthquake records and the effect of vertical components of the earthquakes can also be considered in a further research.

\section{References}

[1] Fujita T. "Seismic isolation of civil buildings in Japan". Progress in Structrutal Engineering and Materials, 1(3), 295-300, 1998.

[2] Matsagar VA, Jangid RS. "Influence of isolator characteristics on the response of base-isolated structures". Engineering Structures, 26(12), 1735-1749, 2004.

[3] Dezfuli FH, Alam MS. "Performance-based assessment and design of FRP-based high damping rubber bearing incorporated with shape memory alloy wires". Engineering Structures, 61, 166-183, 2014.

[4] Dezfuli FH, Alam MS. "Effect of different steel-reinforced elastomeric isolators on the seismic fragility of a highway bridge". Structural Control and Healt Monitoring, 24(2), 1-15, 2017.

[5] Makris N, Chang S. "Effects of damping mechanisms on the response of seismically isolated structures". PEER report 1998/06. Berkeley (CA): Pacific Earthquake Engineering Research Center, College of Engineering, University of California, 1998

[6] Kelly JM, Hodder SB. "Experimental study of lead and elastomeric dampers for base isolation system in laminated neoprene bearings". Bulletin of New Zealand National Society for Earthquake Engineering, 15, 53-67, 1982.

[7] Providakis CP. "Pushover analysis of base-isolated steelconcrete composite structures under near-fault excitations". Soil Dynamics and Earthquake Engineering, 28(4), 293-304, 2008.

[8] ASCE. "Evaluation findings for skellerup base isolation elastomeric bearings". Technical Evaluation Report, (CERF Report: HITEC 98-12), Prepared by the Highway Innovative Technology Evaluation Center, 1998.

[9] Hameed A, Koo MS, Jeong JH. "Effect of lead rubber bearing characteristics on the response of seismic-isolated bridges". KSCE Journal of Civil Engineering, 12(3), 187-196, 2008.

[10] Hashemi S, Aghashiri MH. "Seismic responses of baseisolated flexible rectangular fluid containers under horizontal ground motion". Soil Dynamics and Earthquake Engineering, 100, 159-168, 2017

[11] Jangid RS. "Optimal lead-rubber isolation bearings for near-fault motions". Engineering Structures, 29(10), 2503-2513, 2007.
[12] Bhandari M, Bharti SD, Shrimali MK, Datta TK. "Assessment of proposed lateral load patterns in pushover analysis for base isolated frames". Engineering Structures, 175, 531-548, 2018.

[13] Liang B, Shishu X, Jiaxiang T. "Wind effects on habitability of base-isolated buildings". Journal of Wind Engineering and Industrial Aerodynamics, 90(12-15), 1951-1958, 2002.

[14] Kulkarni JA, Jangid RS. "Effects of superstructure flexibility on the response of base-isolated structures". Shock and Vibration, 10, 1-13, 2003.

[15] Fragiacomo M, Rajgelj S, Cimadom F. "Design of bilinear hysteretic isolation systems". Earthquake Engineering and Structural Dynamics, 32(9), 1333-1352, 2003.

[16] Matsagar VA, Jangid RS. "Influence of isolator characteristics on the response of base-isolated structures". Engineering Structures, 26(12), 1735-1749, 2004.

[17] Alhan C, Şahin F. "Protecting vibration-sensitive contents: an investigation of floor accelerations in seismically isolated buildings". Bulletin of Earthquake Engineering, 9, 1203-1226, 2011.

[18] Özdemir G, Akyüz U. "Performance of a multi-story isolated building subjected to bidirectional excitations in protection of critical equipments from earthquake hazard". 15th World Conference on Earthquake Engineering, Lisboa, Protugal, 24-29 September 2012.

[19] Das S, Mishra SK. "Optimal performance of buildings isolated by shape-memory-alloy-rubber-bearing (smarb) under random earthquakes". International Journal for Computational Methods in Engineering Science and Mechanics, 15(3), 265-276, 2014.

[20] Bhagat S, Wijeyewickrema AC. "Seismic response evaluation of base-isolated reinforced concrete buildings under bidirectional excitation". Earthquake Engineering and Engineering Vibration, 16(2), 365-382, 2017.

[21] Güneyisi EM, Deringöl AH. "Seismic response of friction damped and base-isolated frames considering serviceability limit state". Journal of Constructional Steel Research, 148, 639-657, 2018.

[22] Karavasilis TL, Bazeos N, Beskos DE. "Maximum displacement profiles for the performance based seismic design of plane steel moment resisting frames". Engineering Structures, 28(1), 9-22, 2006.

[23] ASCE 7-05. "Minimum Design Loads for Buildings and Other Structures". American Society of Civil Engineers, Reston, Virginia, 2005.

[24] Eurocode, EN 1998-1 Eurocode 8. "Design of Structures for Earthquake Resistance, European Committee for Standardization". CEN, Brussels, 2004.

[25] TSCB. "Turkish Seismic Code for Buildings". The Disaster and Emergency Management Presidency of Turkey, Ankara, Turkey 2018.

[26] Naeim F, Kelly JM. Design of Seismic Isolated Structures, From Theory to Practice. $1^{\text {st }}$ ed. New York, NY, USA, John Wiley and Sons, 1999.

[27] Ryan L, Chopra AK. "Estimation of seismic demands on isolators based on nonlinear analysis". Journal of Structural Engineering, ASCE, 130(3), 392-402, 2004.

[28] Park Y, Wen JYK, Ang AH. "Random vibration of hysteretic systems under bi-directional ground motions". Earthquake Engineering and Structural Dynamics, 14(4), 543-557, 1986. 
[29] Computers and Structures, (CSI) Inc. "SAP2000 Advanced 14.0.0 Software. Structural Analysis Program". Berkeley, California, 2011.

[30] PEER. "The Pacific Earthquake Engineering Research Center, User's Manual for the PEER Ground Motion Database Application". University of California, Berkeley, 2011.

[31] American Society of Civil Engineers, ASCE. "Minimum design loads for buildings and other structures". ASCE/SEI 7-10, Reston, VA, 2010.
[32] SEAOC Seismology Committee. "Recommended Lateral Force Requirements and Commentary". Structural Engineers Association of California, Sacramento, Uniform Building Code, 1999.

[33] FEMA P750. "NEHRP Recommended Seismic Provisions for New Buildings and Other Structures". Washington, D.C., 2009. 